\title{
A novel mouse model of creatine transporter deficiency
}

\section{[version 1; peer review: 1 approved, 2 approved with}

\section{reservations]}

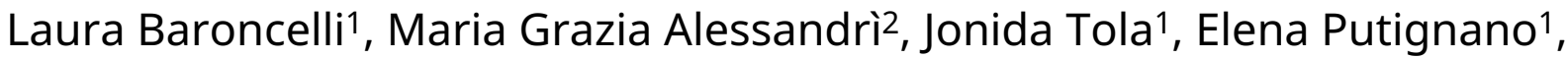 Martina Migliore ${ }^{1}$, Elena Amendola 3 , Cornelius Gross ${ }^{3}$, Vincenzo Leuzzi ${ }^{4}$, Giovanni Cioni2,5, Tommaso Pizzorusso ${ }^{1,6}$}

\footnotetext{
${ }^{1}$ Institute of Neuroscience, National Research Council (CNR), Pisa, I-56124, Italy

2Department of Developmental Neuroscience, IRCCS Stella Maris Scientific Institute, Calambrone (Pisa), I-56128, Italy

${ }^{3}$ Mouse Biology Unit, European Molecular Biology Laboratory (EMBL), Monterotondo (Roma), I-00015, Italy

${ }^{4}$ Department of Paediatrics, Child Neurology and Psychiatry, Sapienza University of Rome, Rome, I-00185, Italy

${ }^{5}$ Department of Clinical and Experimental Medicine, University of Pisa, Pisa, I-56126, Italy

${ }^{6}$ Department of Neuroscience, Psychology, Drug Research and Child Health NEUROFARBA, University of Florence, Florence, I-50135, Italy
}

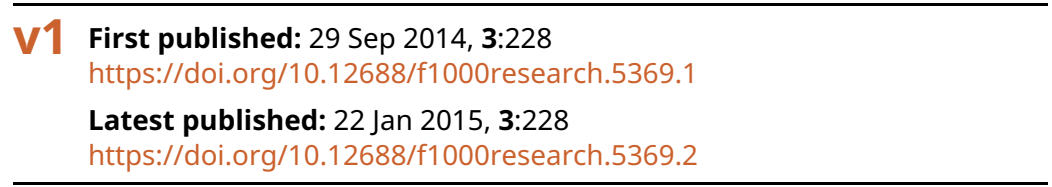

\section{Abstract}

Mutations in the creatine $(\mathrm{Cr})$ transporter $(\mathrm{CrT})$ gene lead to cerebral creatine deficiency syndrome-1 (CCDS1), an X-linked metabolic disorder characterized by cerebral Cr deficiency causing intellectual disability, seizures, movement and behavioral disturbances, language and speech impairment ( OMIM \#300352).

CCDS1 is still an untreatable pathology that can be very invalidating for patients and caregivers. Only two murine models of CCDS1, one of which is an ubiquitous knockout mouse, are currently available to study the possible mechanisms underlying the pathologic phenotype of CCDS1 and to develop therapeutic strategies. Given the importance of validating phenotypes and efficacy of promising treatments in more than one mouse model we have generated a new murine model of CCDS1 obtained by ubiquitous deletion of 5-7 exons in the S/c6a8 gene. We showed a remarkable $\mathrm{Cr}$ depletion in the murine brain tissues and cognitive defects, thus resembling the key features of human CCDS1. These results confirm that CCDS1 can be well modeled in mice. This $\mathrm{CrT}^{-/ y}$ murine model will provide a new tool for increasing the relevance of preclinical studies to the human disease.

Keywords

creatine transporter, mouse model, creatine deficiency syndrome 1

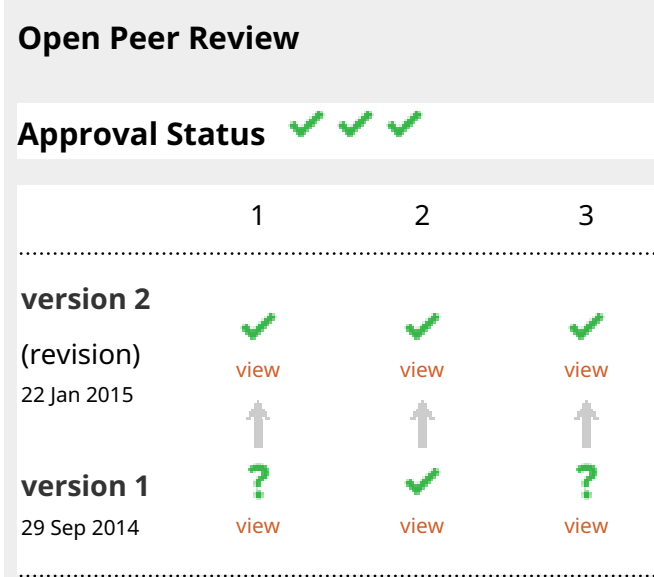

1. Benedetto Sacchetti, University of Turin,

Turin, Italy

2. Luis M. Valor, Instituto de Neurociencias de Alicante (Universidad Miguel Hernández Consejo Superior de Investigaciones Científicas), Alicante, Spain

3. Andreas Schulze, University of Toronto, Toronto, Canada

Any reports and responses or comments on the article can be found at the end of the article. 
Corresponding author: Laura Baroncelli (baroncelli@in.cnr.it)

Competing interests: No competing interests were disclosed.

Grant information: The author(s) declared that no grants were involved in supporting this work.

Copyright: @ 2014 Baroncelli $L$ et al. This is an open access article distributed under the terms of the Creative Commons Attribution License, which permits unrestricted use, distribution, and reproduction in any medium, provided the original work is properly cited. Data associated with the article are available under the terms of the Creative Commons Zero "No rights reserved" data waiver (CC0 1.0 Public domain dedication).

How to cite this article: Baroncelli L, Alessandrì MG, Tola J et al. A novel mouse model of creatine transporter deficiency [version 1; peer review: 1 approved, 2 approved with reservations] F1000Research 2014, 3:228 https://doi.org/10.12688/f1000research.5369.1

First published: 29 Sep 2014, 3:228 https://doi.org/10.12688/f1000research.5369.1 


\section{Introduction}

The creatine $(\mathrm{Cr})$ transporter $(\mathrm{CrT}$, alias CRTR, MGC87396, CT1, SLC6A8, OMIM 300036) deficiency (CCDS1, OMIM \#300352) is an X-linked inherited metabolic disorder characterized by cerebral $\mathrm{Cr}$ deficiency which results in intellectual disability, language and speech impairment, seizures and movement and behavioral disturbances, and affects about $1 \%$ of males with non-syndromic mental disability (van de Kamp et al., 2014). CrT loss of function is mostly caused by missense mutations and small deletions which are concentrated in the transmembrane domains 7 and 8 of the protein (van de Kamp et al., 2014). In physiological conditions, about half of our normal $\mathrm{Cr}$ requirement is satisfied by the diet. De novo endogenous synthesis of $\mathrm{Cr}$ takes place mainly in the kidney, liver and pancreas and involves the enzymes 1-arginine: glycineamidinotransferase (AGAT) and S-adenosyl-1-methionine: $\mathrm{N}$-guanidinoacetatemethyltransferase (GAMT) (Wyss \& Kaddurah-Daouk, 2000). Cr is a polar hydrophilic molecule unable to cross the lipidic membranes, which uses a $\mathrm{Na}^{+}$- and $\mathrm{Cl}^{-}$- dependent plasma membrane $\mathrm{CrT}$ to enter the cells (Nash et al., 1994). CrT is widely expressed in the brain tissue with a prominent presence in the cortical and subcortical regions involved in motor and sensory processing, learning and memory, and regulation of emotion-related behavior (Lowe et al., 2014; Mak et al., 2009).

Patients affected by cerebral creatine deficiency syndrome-1 (CCDS1) share depletion of brain $\mathrm{Cr}$ and the clinical phenotype with patients carrying the other two defects of $\mathrm{Cr}$ metabolism which involve mutations of genes encoding the biosynthesizing enzymes AGAT and GAMT (Item et al., 2001; Stockler et al., 1994). Replenishment of the brain $\mathrm{Cr}$ pool is the only effective therapy for $\mathrm{Cr}$ deficiency diseases (Battini et al., 2002; Schulze et al., 2001; Stockler et al., 1996). Unfortunately, in CCDS 1 patients even very high doses of $\mathrm{Cr}$, alone or combined with the $\mathrm{Cr}$ precursors arginine and glycine to stimulate endogenous $\mathrm{Cr}$ synthesis, fail to restore the $\mathrm{Cr}$ content in brain (Chilosi et al., 2008; Valayannopoulos et al., 2012). There have been attempts to normalize the levels of $\mathrm{Cr}$ in the brain with $\mathrm{Cr}$-lipophilic analogs, but these compounds have proven ineffective when administered to patients (Fons et al., 2010). Thus, CCDS1 is still missing an effective treatment.

Preclinical animal models are crucial tools to dissect disease pathogenic mechanisms and develop new therapeutic strategies. Only two murine models of CCDS1 are available so far, and they have only been analyzed at the behavioral and neurochemical level. An ubiquitous CrT knockout mouse model has been generated by deletion of 2-4 exons in the Slc6a8 gene. Learning and memory deficits, impaired motor activity and $\mathrm{Cr}$ depletion in brain and muscles have been reported in animals at three-four months of age (Skelton et al., 2011). Another murine model is based on the use of the CaMKII promoter to drive Cre-recombinase expression, achieving a CrT deletion only in postnatal forebrain excitatory neurons. This strategy was successful in avoiding the peripheral $\mathrm{Cr}$ depletion and the motor deficits shown by germline CrT knockout mouse. Behavioral analysis in mice at 12 months of age revealed learning and memory impairments that could be ameliorated by supplementation of cyclocreatine, a $\mathrm{Cr}$ analog (Kurosawa et al., 2012).
For translational studies, the phenotype variations observed in different mouse models, carrying similar mutations and the effects of genetic backgrounds highlight the importance of validating phenotypes and therapeutic efficacy in multiple models and in different laboratories (Katz et al., 2012). Such validation will hopefully increase the relevance of preclinical studies to the human disease. To increase the number of CCDS1 models, we generated a novel murine model of CCDS1 obtained by ubiquitous deletion of 5-7 exons in the $S l c 6 a 8$ gene. These mice presented a remarkable $\mathrm{Cr}$ depletion in the brain tissue and displayed cognitive defects resembling the key features of human CCDS1, and providing a new promising CCDS1 animal model.

\section{Materials and methods}

\section{Generation of CrT knockout mice}

A Cre-conditional allele of Slc $6 a 8$ has been produced by introducing the loxP sites flanking exon 5-7 of the gene in embryonic stem (ES) cells via homologous recombination (vector PRPGS00081_A_A09 obtained from the NIH Knock-out Mouse Program, KOMP). The presence of lox sites has been checked by sequencing (sequencing service by MWG, Germany). The plasmid was linearized with NruI before electroporation into ES cells (129/Sv x C57BL/6N, clone A8, gift of A. Wutz, Wellcome Trust Centre for Stem Cell Research, Stem Cell Institute, University of Cambridge). G418-resistant clones were identified and screened by long-range PCR (Applied Biosystems Gene AMP PCR system 2700). Hybridization with a specific probe for the $5^{\prime}$ and $3^{\prime}$ arms was used to confirm the PCR results. Two independent positive ES cell clones were injected into C57BL/6N host embryos using a piezo-drill assisted 8-cell stage injection procedure developed at EMBL, Monterotondo Italy. Four out of five offspring (all $>95 \%$ ES cell derived) provided germline transmission. Germline transmission of the allele was confirmed by long-range PCR and the neomycin selection cassette was removed by crossing with FLP recombinase expressing mice (Farley et al., 2000). Germline knockout mice were produced by crossing the constitutive allele to the HPLRT::Cre recombinase deleter mouse (Tang et al., 2002; Figure 1).

\section{Animal housing}

Animals were maintained at $22^{\circ} \mathrm{C}$ under a 12 -h light-dark cycle. Food and water were available ad libitum. All experiments were carried out in accordance with the European Communities Council Directive of 24 November 1986 (86/609/EEC) and were approved by the Italian Ministry of Health (authorization number 147/2014-B). All necessary efforts were made to minimize both stress and the number of animals used. As CrT deficiency is an X-linked pathology and only males are consistently affected, we focused our study on male animals. Young adult males (postnatal day P40 at the beginning of testing) of each genotype ( $\mathrm{CrT}^{-/ y}$ mutants and $\mathrm{CrT}^{+/ y}$ wild-type littermates) were used in behavioral experiments, while a separate group of animals (P30) was assigned to $\mathrm{Cr}$ level assay.

\section{Detection of S/c6a8 mutation by PCR}

Genomic DNA was isolated from mouse tail using a kit, and the protocol suggested by the manufacturer (DNeasy Blood \& Tissue Kit, Qiagen, USA). DNA was amplified for mutant 


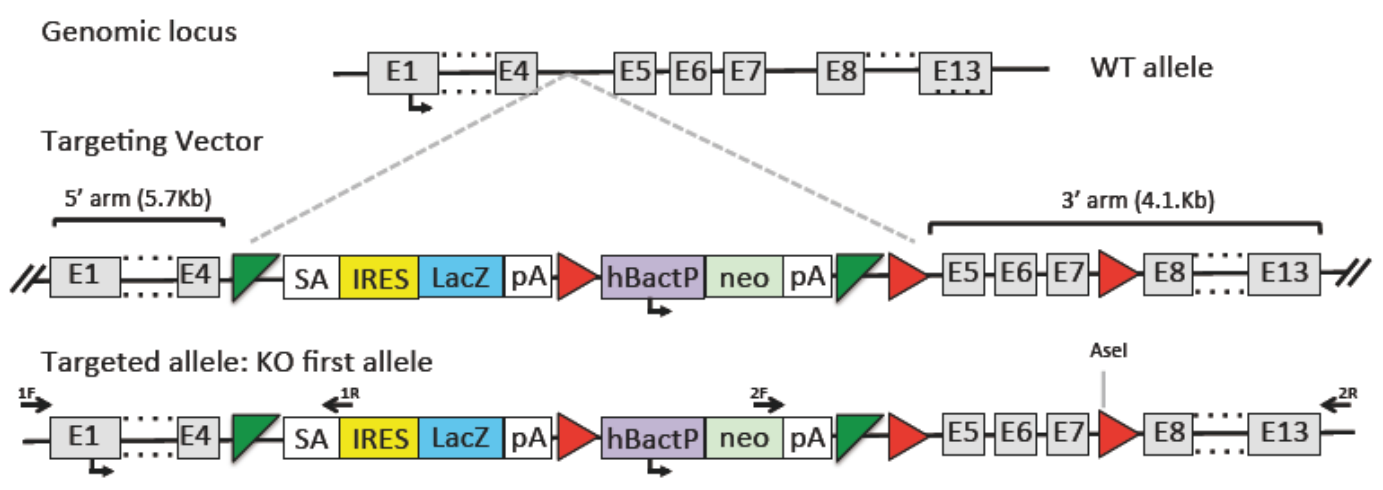

Following Cre expression

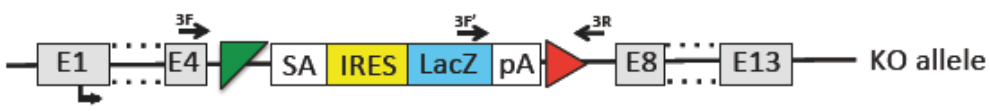

Following Flp expression
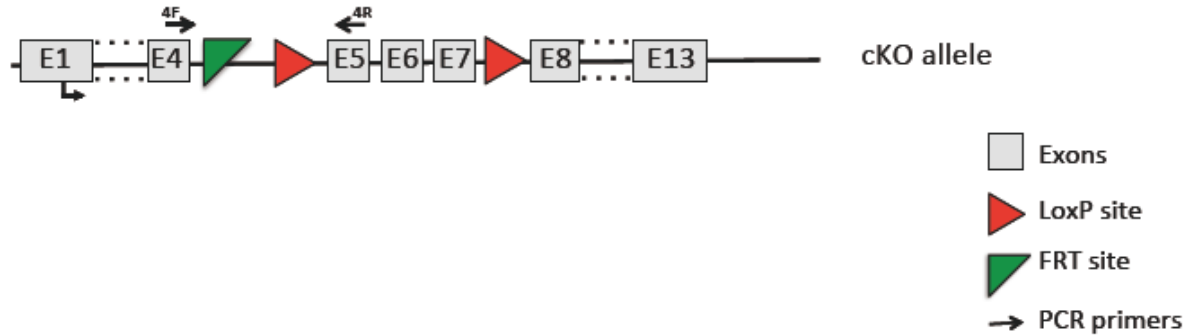

Figure 1. Sketch of the strategy for generation of a null SIc6a8 mouse. A targeting vector was obtained from KOMP to generate mice carrying a floxed allele. Crossing these mice with a Flp deleter mouse line produced a conditional KO mouse line (cKO allele). Crossing this line with a line expressing Cre-recombinase in the germline produced the Slc6a8 null mouse used in this study (KO allele). 1F, 1R, 2F, 2R, 3F, $3 F^{\prime}, 3 R, 4 F, 4 R$ report the sites targeted by the PCR primers to assess allele presence.

and wild-type (WT) allele using a standard PCR protocol with the following primers: F:AGGTTTCCTCAGGTTATAGAGA; R:CCCTAGGTGTATCTAACATCT; R1: TCGTGGTATCGTTATGCGCC. For PCR amplification we used $300 \mathrm{ng}$ of DNA in a $25 \mu \mathrm{L}$ reaction volume containing $0.2 \mathrm{mM}$ of each dNTP, $2 \mu \mathrm{M}$ of $\mathrm{F}$ primer, $1 \mu \mathrm{M}$ of $\mathrm{R}, 1 \mu \mathrm{M}$ of $\mathrm{R} 1$ primer and $0.5 \mathrm{U} / \mu \mathrm{L}$ Red Taq DNA polymerase (Sigma-Aldrich, Italy). The PCR conditions were as follows: $94^{\circ} \mathrm{C}$ for $4 \mathrm{~min}$ followed by 37 cycles at $94^{\circ} \mathrm{C}$ for $30 \mathrm{~s}$, $58^{\circ} \mathrm{C}$ for $30 \mathrm{~s}, 72^{\circ} \mathrm{C}$ for $40 \mathrm{~s}$ and a final extension at $72^{\circ} \mathrm{C}$ for $7 \mathrm{~min}$. Amplicons were separated using $2 \%$ agarose gel and visualized under UV light after staining with Green Gel Plus (Fisher Molecular Biology, Rome, Italy). Amplicon sizes were: WT allele $=462$ bp; mutant allele $=371 \mathrm{bp}$.

\section{Gas chromatography/mass spectrometry (GC/MS)}

Mouse tissues, immediately frozen on dry ice and stored at $-80^{\circ} \mathrm{C}$ until the analysis, were homogenized in $0.7 \mathrm{ml}$ PBS buffer (SigmaAldrich, Italy) at $4^{\circ} \mathrm{C}$ using a ultrasonic disruptor (Microson Heat System, NY, USA) for brain or a glass manual homogenizer (VWR, Italy) for kidney, heart and muscle. After centrifugation $(600 \times \mathrm{g}$ for $10 \mathrm{~min}$ at $\left.4^{\circ} \mathrm{C}\right)$ an aliquot of the homogenate $(50 \mu \mathrm{l})$ was assayed for protein content (Lowry et al., 1951), and the supernatant used for $\mathrm{Cr}$ assay as previously described (Alessandrì et al., 2005). Briefly,
$50 \mu \mathrm{l}$ of saturated sodium hydrogen carbonate and $50 \mu \mathrm{l}$ of a mixture containing 2- phenylbutyric acid (I.S.) in toluene $(6.09 \mathrm{mmol} / \mathrm{l}$; Sigma-Aldrich, Italy) were added to $200 \mu$ of homogenate. After adding $1 \mathrm{ml}$ of toluene and $50 \mu \mathrm{l}$ of hexafluoro-2,4-pentanedione (Sigma-Aldrich, Italy) to form bis-trifluoromethyl- pyrimidine derivatives, the mixture was stirred overnight at $80^{\circ} \mathrm{C}$. The organic layer was centrifuged, dried under nitrogen and $2 \mu$ of the residue derivatized at room temperature with $100 \mu \mathrm{l}$ of BSTFA+TMCS (Sigma-Aldrich, Italy) injected into the GC/MS. GC analyses were performed using an Agilent $6890 \mathrm{~N}$ GC equipped with an HP5MS capillary column $(0.25 \mathrm{~mm} \times 30 \mathrm{~m}$, film thickness $0.25 \mathrm{im})$ and an Agilent mass spectrometer 5973N (Agilent Technologies, Italy). The mass spectrometer was set in EI- single ion monitoring mode (SIM). The ions with m/z of 192 for I.S., 258 for $\mathrm{Cr}$ and 225 for guanidinoacetic acid (GAA) were used for calculation of the metabolites, using standard curves ranging 5-90 $\mu \mathrm{mol} / \mathrm{L}$ and $0.30-6 \mu \mathrm{mol} / \mathrm{L}$ for $\mathrm{Cr}$ and GAA, respectively. Data were processed by the G1701DA MSD ChemStation software. All the aqueous solutions were prepared using ultrapure water produced by a Millipore system.

\section{Behavioral testing}

The testing order consisted of: open field (1 day duration), object recognition test (ORT) at 24h (3 days), Y maze (1 day), Morris 
water maze (MWM) with hidden platform (7 days), and locomotor activity ( 1 day). The mice were tested on one task at a time with the next behavioral test starting at least 2 days after the completion of the previous one. In order to reduce the circadian effects, all behavioral tests were performed during the same time interval each day (1400-1800h; light phase). All behavioral tests were conducted in blind with respect to the genotype of animals. Mice were weighed at the end of experiments (P60).

\section{Open field and object recognition test (ORT)}

We followed the protocol reported in Lonetti et al., 2010. Briefly, the apparatus consisted of a square arena $(60 \times 60 \times 30 \mathrm{~cm})$ constructed in poly(vinyl chloride) with black walls and a white floor. The mice received two sessions of 10-min duration in the empty arena on two consecutive days to habituate them to the apparatus and test room. Animal position was continuously recorded by a video tracking system (Noldus Ethovision XT). In the recording software an area corresponding to the center of the arena (a central square $30 \times 30 \mathrm{~cm}$ ), and a peripheral region (corresponding to the remaining portion of the arena) were defined. The total movement of the animal and the time spent in the center or in the periphery area were automatically computed. The mice activity during the first day of habituation was analyzed for evaluating the behavior in the open field arena. The ORT consisted of two phases: sample and testing phase. During the sample phase, two identical objects were placed in diagonally opposite corners of the arena, approximately $6 \mathrm{~cm}$ from the walls, and mice were allowed $10 \mathrm{~min}$ to explore the objects, then they were returned to their cage. The objects to be discriminated were made of plastic, metal, or glass material and were too heavy to be displaced by the mice. Arena and objects were cleaned with $10 \%$ ethanol between trials to stop the build-up of olfactory cues. The testing phase was performed $24 \mathrm{~h}$ after the sample phase. One of the two familiar objects was replaced with a new one, while the other object was replaced by an identical copy. The objects were placed in the same locations as the previous ones. The mice were allowed to explore objects for $5 \mathrm{~min}$. To avoid possible preferences for one of two objects, the choice of the new and old object and the position of the new one were randomized among animals. The amount of time spent exploring each object (nose sniffing and head orientation within $<1.0 \mathrm{~cm}$ ) was recorded and evaluated by the experimenter blind to the mouse genotype. Mice exploring the two objects for less than $10 \mathrm{~s}$ during the sample phase were excluded from testing. A discrimination index was computed as $\mathrm{DI}=\left(\mathrm{T}_{\text {new }}-\mathrm{T}_{\text {old }}\right) /\left(\mathrm{T}_{\text {new }}+\mathrm{T}_{\text {old }}\right)$, where $\mathrm{T}_{\text {new }}$ is the time spent exploring the new object, and $\mathrm{T}_{\text {old }}$ is the time spent exploring the old one.

\section{Y maze}

Spontaneous alternation was measured using the Y-maze, as described in Begenisic et al., 2014. We used a Y-shaped maze with three symmetrical grey solid plastic arms at a 120-degree angle (26 cm length, $10 \mathrm{~cm}$ width, and $15 \mathrm{~cm}$ height). Mice were placed in the center of the maze and allowed to freely explore the maze for 8 minutes. The apparatus was cleaned with $10 \%$ ethanol between trials to avoid the build-up of odor traces. All sessions were videorecorded for offline blind analysis. The arm entry was defined as all four limbs within the arm. A triad was defined as a set of three arm entries, when each entry was to a different arm of the maze. The number of arm entries and the number of triads were recorded in order to calculate the alternation percentage (generated by dividing the number of triads by the number of possible alternations and then multiplying by 100).

\section{Morris water maze}

Mice were trained for four trials per day and for a total of 7 days in a circular water tank, made from grey polypropylene (diameter, $120 \mathrm{~cm}$; height, $40 \mathrm{~cm})$, filled to a depth of $25 \mathrm{~cm}$ with water $\left(23^{\circ} \mathrm{C}\right)$ rendered opaque by the addition of a small amount of a non-toxic white paint. Four positions around the edge of the tank were arbitrarily designated North $(\mathrm{N})$, South $(\mathrm{S})$, East (E), and West (W), which provided four alternative start positions and also defined the division of the tank into four quadrants, i.e., NE, SE, SW, and NW. A square clear Perspex escape platform $(11 \times 11 \mathrm{~cm})$ was submerged $0.5 \mathrm{~cm}$ below the water surface and placed at the midpoint of one of the four quadrants. The hidden platform remained in the same quadrant during training, while the start positions $(\mathrm{N}, \mathrm{S}$, $\mathrm{E}$, or $\mathrm{W})$ were randomized across trials. Mice were allowed up to $60 \mathrm{~s}$ to locate the escape platform, and their swimming paths were automatically recorded by the Noldus Ethovision system. On the last trial of the last training day, mice received a probe trial, during which the escape platform was removed from the tank and the swimming paths were recorded over $60 \mathrm{~s}$ while mice searched for the missing platform. The swimming paths were recorded and analyzed with the Noldus Ethovision system.

\section{Measurement of spontaneous locomotor activity} Opto M3 multi-channel activity monitors (Columbus Instruments, $\mathrm{OH}, \mathrm{USA}$ ) were used to quantify spontaneous horizontal activity of animals. Monitors were placed in the colony area and testing was conducted in the same conditions of animal facility housing. All measurements were performed from 6:00 P.M. to 6:00 A.M. (dark phase) and to 6:00 A.M. to 6:00 P.M. (light phase), using animals maintained on a $12 \mathrm{hr}$ light/dark cycle from 6:00 A.M. to 6:00 P.M. Individual mice were placed in $33 \times 15 \times 13-\mathrm{cm}$ (length $\times$ width $\times$ height) clear plastic cages for $24 \mathrm{~h}$ and total distance travelled was calculated from infrared beam breaks by determining activity at 1-min intervals. Horizontal activity was measured by the sequential breaking of infrared beams, $2.54 \mathrm{~cm}$ on center, in the horizontal plane of the $\mathrm{x}$ axis.

\section{Statistical analysis}

All statistical analyses were performed using SigmaStat Software. Differences between two groups were assessed with a two-tailed $\mathrm{t}$ test. The significance of factorial effects and differences among more than two groups were evaluated with ANOVA/RM ANOVA followed by Holm-Sidak test. Rank transformation was exploited for data not normally distributed. The level of significance was $\mathrm{p}<0.05$.

\section{Results}

$\mathrm{CrT}$ deletion leads to significant $\mathrm{Cr}$ reduction in brain and other tissues

In order to determine the effectiveness of our approach for targeting $\mathrm{CrT}$ gene, the $\mathrm{Cr}$ levels were measured by GC/MS in various tissues. We observed a significant reduction of $\mathrm{Cr}$ in the brain (both cerebral cortex and hippocampus; Two Way ANOVA on ranks, post hoc Holm-Sidak method, $\mathrm{p}<0.01$ and $\mathrm{p}<0.001$ respectively), muscle 
$(\mathrm{p}<0.01)$, heart $(\mathrm{p}<0.001)$ and kidney $(\mathrm{p}<0.05)$ of $\mathrm{CrT}^{-/ y}$ mice with respect to wild-type (WT) littermates $(n=4 /$ tissue for each group; Table 1). To ensure that kidney $\mathrm{Cr}$ reduction was not due to impaired $\mathrm{Cr}$ biosynthesis, we also measured kidney production of guanidinoacetic acid (GAA). No difference was observed between $\mathrm{CrT}^{-/ y}(9.76 \pm 0.71 \mathrm{nmol} / \mathrm{mg}$ of protein $)$ and $\mathrm{CrT}^{+/ y}$ mice $(10.70 \pm$ $0.63 \mathrm{nmol} / \mathrm{mg}$ of protein; $\mathrm{t}$ test, $\mathrm{p}=0.359)$.

\section{Reduced body weight growth in $\mathrm{CrT}^{-1 /}$ mice at two months} of age

The general appearance of $\mathrm{CrT}^{-/ y}$ mice was normal and no particular problems of breeding were observed. To evaluate the effects of CrT deletion on body weight, the mice with targeted disruption of CrT gene were weighed at P60, and compared with WT littermates. $\mathrm{CrT}^{-/ y}$ animals $(\mathrm{n}=9)$ showed a significantly reduced body weight compared to $\mathrm{CrT}^{+/ y}$ animals ( $\mathrm{n}=9$; $\mathrm{t}$ test, $\mathrm{p}<0.01$; Figure 2 ).

Normal behavior of $\mathrm{CrT}^{-1 /}$ mice in the open field arena We first analyzed the general motor activity and anxiety-related behavior of $\mathrm{CrT}^{-/ y}(\mathrm{n}=9)$ and $\mathrm{CrT}^{+/ y}$ mice $(\mathrm{n}=9)$ in the open field arena. Even though both groups of animals tended to avoid the

Table 1. Depletion of $\mathrm{Cr}$ levels in $\mathrm{CrT}^{-/ y}$ mutant mice. Cr levels (mean \pm SEM) in $\mathrm{CrT}^{-1 / y}$ and $\mathrm{Cr}^{+/ y}$ animals $(n=4$ per tissue for both groups). Cr levels have been measured by GC/MS. A reduction of $\mathrm{Cr}$ content was evident in the brain, muscle, heart and kidney tissue of mutant animals (Two Way ANOVA on ranks, post hoc Holm-Sidak method). ${ }^{*} p<0.05 ;{ }^{* \star} p<0.01 ;{ }^{* \star *} p<0.001$.

\begin{tabular}{|c|c|c|}
\hline $\begin{array}{c}\text { Tissue (nmol/mg } \\
\text { protein) }\end{array}$ & CrT $^{-/ \mathbf{y}}$ & $\mathbf{C r T}^{+/}$ \\
\hline Cerebral cortex & $13.61 \pm 1.06^{\star \star}$ & $76.36 \pm 3.16$ \\
\hline Hippocampus & $14.14 \pm 1.52^{\star \star \star}$ & $83.69 \pm 4.37$ \\
\hline Muscle & $111.57 \pm 21.27^{\star \star}$ & $310.20 \pm 31.59$ \\
\hline Heart & $1.19 \pm 0.27^{\star \star \star}$ & $89.92 \pm 5.15$ \\
\hline Kidney & $1.59 \pm 0.13^{\star}$ & $9.60 \pm 0.65$ \\
\hline
\end{tabular}

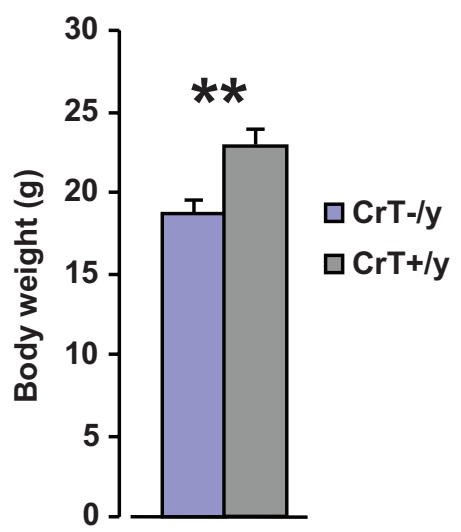

Figure 2. Body weight is lower in $\mathrm{CrT}^{-/ y}$ animals at two months of age. At P60 the weight of $\mathrm{CrT}^{-1 / y}$ mice was significantly reduced compared to $\mathrm{CrT}^{+/ y}$ animals (CrT ${ }^{-1 / y}: 18.75 \pm 0.78 \mathrm{~g}$, $\mathrm{CrT}^{+/ y}: 22.77 \pm$ $0.90 \mathrm{~g}$; t test, $\mathrm{p}<0.01)$. ${ }^{*}$, statistical significance. Error bars, s.e.m. center of the arena, remaining in the peripheral region for a significantly longer duration (Two Way ANOVA, post hoc Holm-Sidak method), the time spent by $\mathrm{CrT}^{-/ y}$ mutant mice in both the central and peripheral portion of the apparatus was not different from that recorded for WT animals (Two Way ANOVA, post hoc Holm-Sidak method, $p=0.725$ and $p=0.922$ respectively; Figure $3 a, b, e)$. No difference between $\mathrm{CrT}^{-/ y}$ and $\mathrm{CrT}^{+/ y}$ animals was present even in motion speed and total distance moved ( $\mathrm{t}$ test, $\mathrm{p}=0.807$ and $\mathrm{p}=0.736$ respectively; Figure $3 \mathrm{c}, \mathrm{d})$.

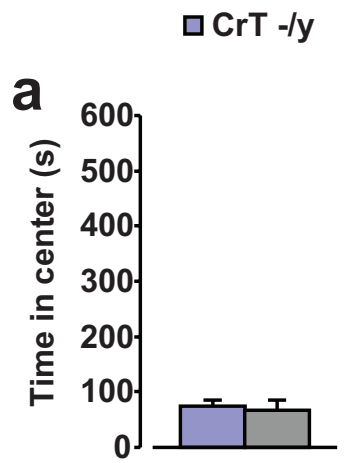

$\square \mathrm{Crt}+/ \mathbf{y}$
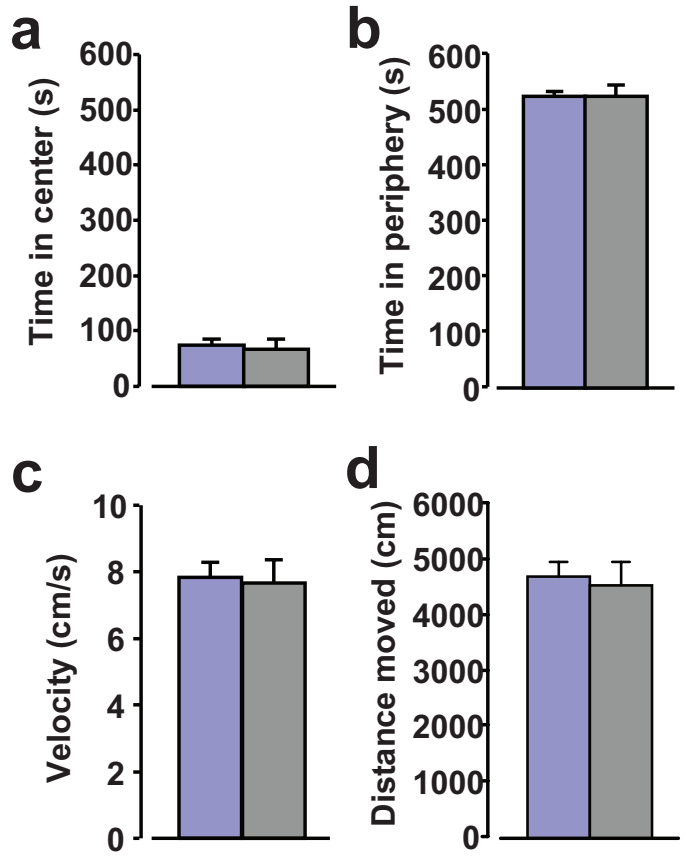

e
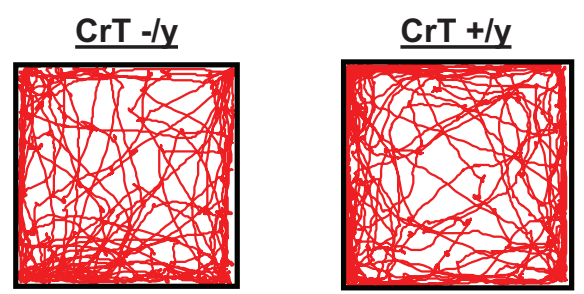

Figure 3. Normal behavior of CrT mutant mice in the open field arena. $(\mathbf{a}, \mathbf{b}) \mathrm{CrT}^{-1 / y}(n=9)$ and $\mathrm{CrT}^{+/ y}$ mice $(n=9)$ spent a comparable amount of time in the center (CrT-1/: $75.16 \pm 10.82 \mathrm{~s}$, $\left.\mathrm{CrT}^{+/ y}: 67.60 \pm 18.11 \mathrm{~s} ; \mathbf{a}\right)$ and in the peripheral region ( $\mathrm{CrT}^{-1 / y}: 524.41$ $\pm 10.87 \mathrm{~s}, \mathrm{CrT}^{+/ y}: 526.52 \pm 18.45 \mathrm{~s}$; b) of the open field arena. A Two-Way ANOVA analysis shows no significant effect of genotype for both comparisons ( $p=0.725$ and $p=0.922$, respectively). (c) Walking speed of animals during the exploration of open field arena. We found no significant difference $\left(\mathrm{CrT}^{-1 / \mathrm{y}}: 7.85 \pm 0.43 \mathrm{~cm} / \mathrm{s}, \mathrm{CrT}^{+/ \mathrm{y}}\right.$ : $7.65 \pm 0.71 \mathrm{~cm} / \mathrm{s}$; t test, $p=0.807)$. (d) The total distance moved in the open field arena did not differ between CrT mutants (4706.34 \pm $258.75 \mathrm{~cm})$ and WT animals $(4535.28 \pm 427.11 \mathrm{~cm}$; t test, $p=0.736)$. (e) Representative examples of movement path during the open field session for a $\mathrm{CrT}^{-1 y}$ (left) and a $\mathrm{CrT}^{+/ y}$ mouse (right). Error bars, s.e.m. 
$\mathrm{CrT}^{-1 y}$ mice display declarative memory deficits in the object recognition test

We assessed declarative memory abilities in the object recognition test (ORT) evaluating animal ability to discriminate a new versus a familiar object. During the sample phase (Figure 4a), all experimental groups equally explored the objects, with a total exploration time of mutant mice $(n=8)$ very close to that recorded for the control group $(n=6 ; t$ test, $p=0.358)$. After a delay of $24 \mathrm{~h}$, the testing phase revealed that while $\mathrm{CrT}^{+/ y}$ mice displayed a clear preference toward the novel object spending a significantly longer time exploring it, an impaired performance was found in $\mathrm{CrT}^{-/ y}$ animals, which exhibited a significantly lower discrimination index than control animals (t test, $\mathrm{p}<0.05$, Figure $4 \mathrm{~b}$ ).

Impaired spatial working memory in $\mathrm{CrT}^{-1 / y}$ mice

To evaluate whether CrT deletion may affect spatial working memory, we used the analysis of spontaneous alternation in the Y maze
(Figure 5a). Animals of both groups equally explored all the three arms of the maze. Indeed, no effect of genotype was detected for either the number of entries in the single arms of the maze (designated A, B, C) or the total number of arm entries, indicating that the exploratory disposition of mutant animals $(n=9)$ was not altered compared to WT littermates $(\mathrm{n}=9$; Two-Way ANOVA, post hoc Holm-Sidak method, $p=0.640, p=0.966, p=0.252, p=0.523$ respectively, Figure $5 \mathrm{~b}$ ). In contrast, $\mathrm{CrT}^{-/ y}$ mice showed a significantly smaller rate of spontaneous alternation with respect to WT controls (t test, $\mathrm{p}<0.05$, Figure $5 \mathrm{c}$ ).

CrT deletion impairs spatial learning and memory in mutant mice

We further assessed spatial memory abilities in the Morris water maze (MWM) task, a cognitive paradigm which allows testing both spatial learning and memory. Since a main effect of genotype was found on mean swimming speed recorded all along the training a
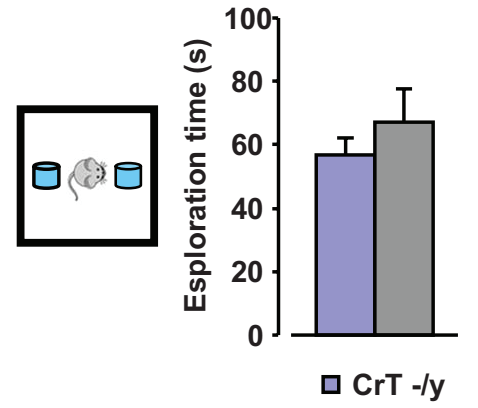

b

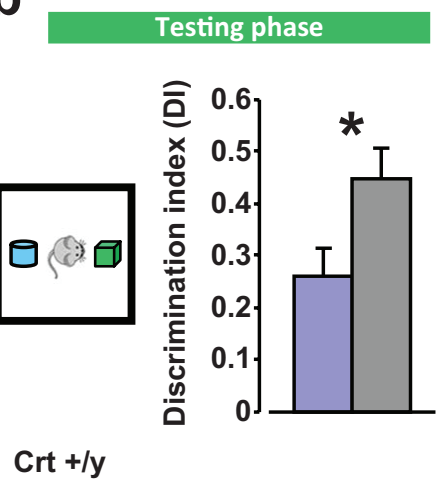

Figure 4. CrT deletion leads to cognitive deficits in object recognition memory. (a) On the left, a schematic representation of the sample condition in object recognition task. Histograms depict the performance of $\mathrm{CrT}^{-1 / y}$ and $\mathrm{CrT}^{+\mathrm{y}}$ during the sample phase: no difference in the total exploration time of objects was detected between the experimental groups (CrT-1y: $n=8$, exploration time $=56.91 \pm 5.40 \mathrm{~s} ; \mathrm{CrT}^{+/ y}$ : $n=6$, exploration time $=67.20 \pm 10.23 \mathrm{~s}$; t test, $\mathrm{p}=0.358$ ). (b) On the left, a schematic diagram of the test condition. Histograms display object discrimination indexes of $\mathrm{CrT}^{-1 / y}$ and $\mathrm{CrT}^{+y}$ during the testing phase: a significantly lower discrimination index was found in $\mathrm{CrT}^{-1 / y}$ mice $(0.261 \pm$ 0.053) compared to $\mathrm{CrT}^{+\mathrm{y}}$ animals $(0.448 \pm 0.059$; t test, $\mathrm{p}<0.05) .{ }^{*}$, statistical significance. Error bars, s.e.m.

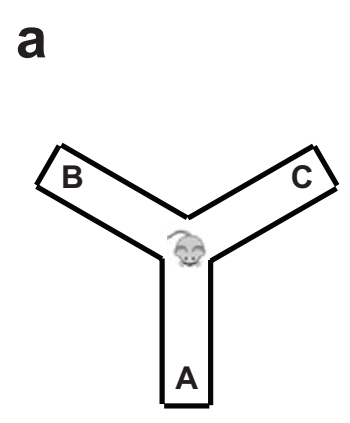

b

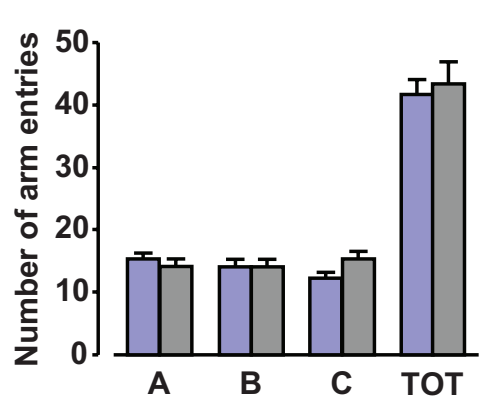

C

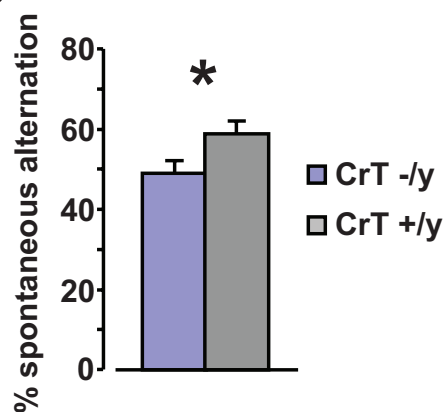

Figure 5. Impairment of Y-maze spontaneous alternation rate in $\mathbf{C r T}^{-1 /}$ mice. (a) Schematic diagram of the $Y$ maze apparatus. (b) Histograms depict the mean number of entries in the single arms of the maze (A, B, C) and the total number of arm entries for the different experimental groups: animals of both groups equally explored all the three arms of the maze and general exploratory behavior of $\mathrm{CrT}^{-1 / y}$ animals $(n=9 ; A: 15.22 \pm 1.12$, B: $14.22 \pm 1.08, C: 12.22 \pm 1.05$, TOT: $41.67 \pm 2.41)$ was totally comparable to that exhibited by WT littermates $(\mathrm{n}=9$; $\mathrm{A}: 14.00 \pm 1.26, \mathrm{~B}: 14.11 \pm 1.29, \mathrm{C}: 15.22 \pm 1.27$, TOT: $43.33 \pm 3.58$; Two-Way ANOVA, post hoc Holm-Sidak method, $\mathrm{p}=0.640$, $p=0.966, p=0.252, p=0.523$ respectively). (c) Alternation rate in the $Y$ maze was significantly lower in $\mathrm{CrT}^{-1 / \mathrm{s}}$ mice $(49.24 \pm 3.20 \%)$ compared to that recorded for $\mathrm{CrT}^{+/ y}$ littermates $(58.91 \pm 2.99 \%$; t test, $p<0.05)$. *, statistical significance. Error bars, s.e.m. 
phase ( $t$ test, $\mathrm{p}<0.05$; Figure $6 \mathrm{a}$ ), we analyzed path length, which is a quantity independent of swimming velocity. We found that the mean distance covered to locate the submerged platform on the last three days of training was longer in $\mathrm{CrT}^{-/ y}$ mice $(\mathrm{n}=9)$ compared to $\mathrm{CrT}^{+/ y}$ littermates $(\mathrm{n}=5$; $\mathrm{t}$ test, $\mathrm{p}<0.05$; Figure $6 \mathrm{~b}, \mathrm{c})$. To measure the strength of spatial learning and to discriminate between spatial and non-spatial memory strategies we performed a probe trial in which the hidden platform was removed and the amount of time spent in the former region of the platform was measured. The probe test confirmed the spatial memory impairment of $\mathrm{CrT}^{-/ y}$ mice: $\mathrm{CrT}^{+/ y}$ animals spent significantly longer time in the quadrant where the platform was located during the previous learning days $\left(\mathrm{NE}^{*}\right.$; Two-Way RM ANOVA, post hoc Holm-Sidak method, $\mathrm{p}<0.05$ for all comparisons); in contrast, $\mathrm{CrT}^{-/ y}$ mice showed no preference for the target quadrant, indicating that they did not remember the location of the hidden platform (Two-Way RM ANOVA, post hoc Holm-Sidak method; Figure 6d). A statistically significant effect of genotype was detected in the time spent exploring the target quadrant (Two-Way RM ANOVA, post hoc Holm-Sidak method, $\mathrm{p}<0.05$; Figure 6d).

\section{Cr depletion reduces spontaneous locomotor activity in $\mathrm{CrT}^{-1 y}$ mice}

To investigate the presence of movement impairments in $\mathrm{CrT}^{-/ y}$ mice in a non-aversive environment, we investigated home-cage-locomotor activity. We found that $\mathrm{CrT}^{-/ y}$ mice $(\mathrm{n}=9)$ are significantly less active than the $\mathrm{CrT}^{+/ y}$ group $(\mathrm{n}=8$, Two-Way ANOVA, post hoc Holm-Sidak method, $\mathrm{p}<0.001)$. More specifically, $\mathrm{CrT}^{-/ y}$ mice showed decreased horizontal activity during the night period (TwoWay ANOVA, post hoc Holm-Sidak method, $\mathrm{p}<0.001$ ), while no effect of genotype was observed for exploration during daytime $(\mathrm{p}=0.535 ;$ Figure $7 \mathrm{a}, \mathrm{b})$.

Dataset 1. Data for neurochemical and behavioral assessment in a mouse model of creatine deficiency

http://dx.doi.org/10.5256/f1000research.5369.d36153

Detailed descriptions of each dataset can be found in the text file provided.

\section{Discussion}

We have generated a new murine model of human CrT deficiency carrying a loss of function deletion of 5-7 exons in the murine orthologous of Slc68a gene. Given that most disease-underlying mutations in human CCDS1 lead to loss of CrT function (van de Kamp et al., 2014), our model has a good degree of construct validity. Beyond the genetic deletion, neurochemical abnormalities found in $\mathrm{CrT}^{-/ y}$ mice, reproducing the reduced levels of $\mathrm{Cr}$ that characterize the brain of CCDS1 patients (van de Kamp et al., 2012),
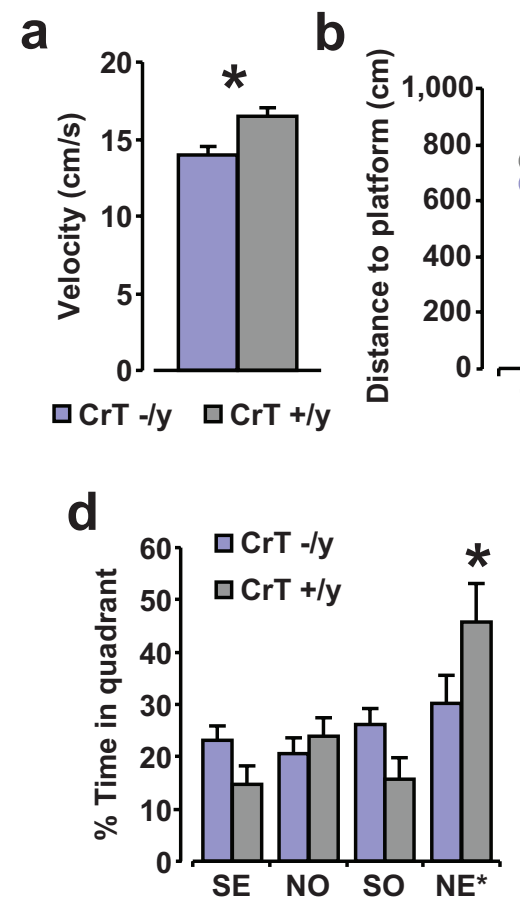
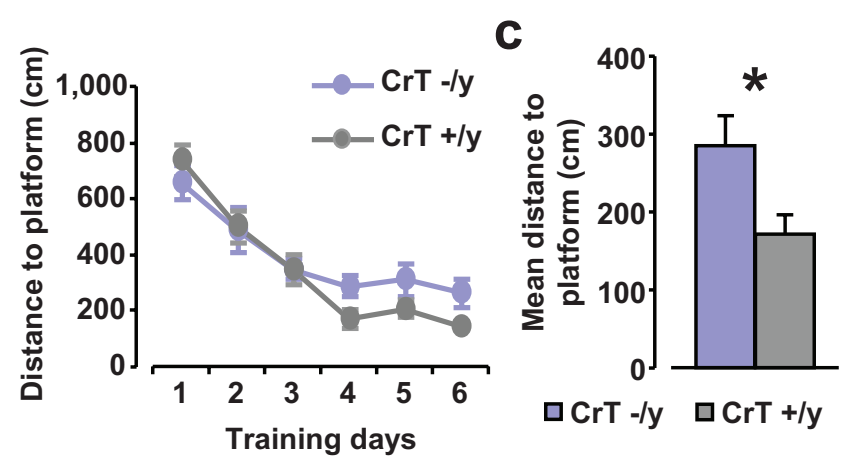

e
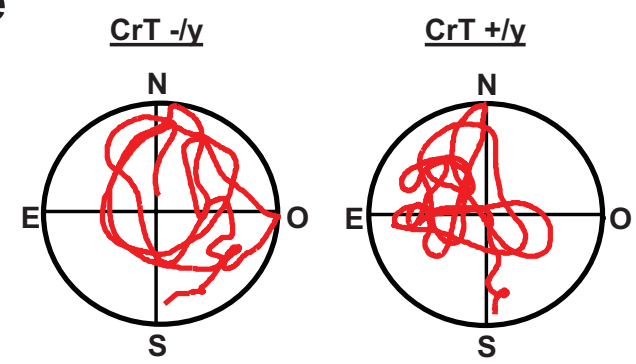

Figure 6. CrT deletion impairs spatial learning and memory in mutant mice. (a) Mean swimming speed measured all along the training phase for $\mathrm{CrT}^{-1 y}$ and $\mathrm{CrT}^{+/ y}$ animals: mutant mice $(14.00 \pm 0.53 \mathrm{~cm} / \mathrm{s})$ resulted to be slower swimmers with respect to control littermates $(16.44 \pm 0.60 \mathrm{~cm} / \mathrm{s}$; t test, $p<0.05)$. (b, c) Learning curves for $\mathrm{CrT}^{-1 / y}\left(n=9\right.$; blue) and $\mathrm{CrT}^{+/ y}$ mice $(n=5$; grey) during the training phase. The histogram shows the mean swimming path covered to locate the submerged platform on the last three day of training for the two groups. A t-test analysis showed a statistical difference between $\mathrm{CrT}^{-1 / y}(285.24 \pm 37.53 \mathrm{~cm})$ and $\mathrm{CrT}^{+/ y}$ animals $(171.58 \pm 23.80 \mathrm{~cm} ; \mathrm{p}<0.05)$. (d) Probe trial. A Two-Way RM ANOVA followed by Holm-Sidak multiple comparison revealed that while $\mathrm{CrT}^{+/ / y}$ spent significantly more time in the NE quadrant than in the other ones, $\mathrm{CrT}^{-1 y}$ did not show any preference for the target quadrant. In addition, the percentage of time spent in the target quadrant was shorter in $\mathrm{CrT}^{-1 / y}$ mice $(30.31 \pm 5.33 \%)$ than in the other group $(45.73 \pm 7.35 \%)$. (e) Representative examples of swimming path during the probe session for a $\mathrm{CrT}^{-1 / y}$ (left) and a $\mathrm{CrT}^{+/ y}$ mouse (right). *, statistical significance. Error bars, s.e.m. 


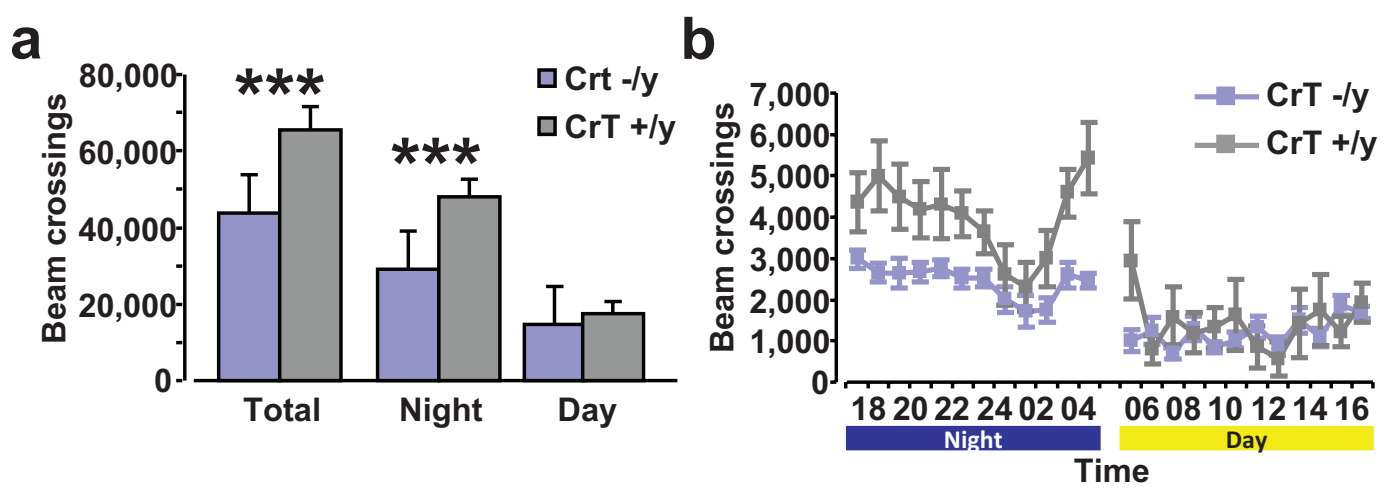

Figure 7. Locomotor activity in $\mathrm{CrT}^{-/ \mathrm{y}}$ mutant mice and the wild-type parental strain. (a) Total horizontal distance travelled throughout $24 \mathrm{~h}$ (left), and over the dark (middle) or light phase (right). CrT-ly mice had a significant decrease in motor activity in comparison to control animals during the whole period of testing ( $\mathrm{CrT}^{-1 y}$ : 43,594.22 $\pm 2,639.39$ beam crossings, $\mathrm{CrT}^{+/ y}$ : 65,587.63 $\pm 5,831.19$ beam crossings) and the night phase (CrT-1y: 29,109.67 \pm 1,695.35 beam crossings, CrT+1y: 48,094.13 \pm 4,843.56 beam crossings; Two-Way ANOVA, post hoc Holm-Sidak method, $p<0.001$ for both comparisons), while the motor behavior of the two groups was similar in the day-time $\left(\mathrm{CrTT}^{-1 / y}: 14,484.56 \pm 1,458.08\right.$ beam crossings, $\mathrm{CrT}^{+/ y}$ : 17,493.50 $\pm 2,957.57$ beam crossings; $\mathrm{p}=0.535$ ). (b) Time course of horizontal activity of $\mathrm{CrT}^{-/ y}$ (blue) and $\mathrm{CrT}^{+/ y}$ (grey) animals during $24 \mathrm{~h}$. Data are plotted as total number of beam crossings \pm SEM in each time block of 60 min. Dark and light phases are indicated. *, statistical significance. Error bars, s.e.m.

are also helpful to confirm the successful disruption of CrT gene and the construct robustness of this model. Importantly, $\mathrm{Cr}$ deficiency is apparent in both the cerebral cortex and hippocampus, i.e., two brain regions crucially involved in the patient cognitive defects. These results seem to support the hypothesis that, despite AGAT and GAMT expression (Carducci et al., 2012; Schmidt et al., 2004; Tachikawa et al., 2004), in CrT deficiency conditions endogenous synthesis does not compensate for the loss of $\mathrm{Cr}$ uptake in the mouse (Skelton et al., 2011) as in the human brain (Cecil et al., 2001). In contrast to the preservation of Cr levels in skeletal muscle of CCDS1 patients (deGrauw et al., 2003), we observed that mutant mice exhibit $\mathrm{Cr}$ reductions in muscle and other peripheral tissues. This observation is in agreement with data showing that skeletal muscle tissue from a different CrT knockout mouse displayed a dramatic reduction of Cr levels (Russell et al., 2014; Skelton et al., 2011).

Our behavioral investigation highlighted that $\mathrm{CrT}^{-/ y}$ mice carrying a different deletion than previously reported (Skelton et al., 2011) exhibit a broad spectrum of phenotypes establishing the validity of this model and corroborating its utility in translational studies. Mutant mice, indeed, show cognitive impairments in a battery of learning and memory tests aimed at assessing both explicit and implicit memories such as object-recognition task, Y maze and Morris water maze. The memory deficiency assessed across a variety of behavioral tasks indicates that $\mathrm{CrT}^{-/ y}$ animals have a general cognitive impairment, which is a key clinical feature in CCDS1 patients.

While the motor development is only mildly delayed in CCDS1 patients (van de Kamp et al., 2013) and myopathic symptoms have been rarely described (Anselm et al., 2006; van de Kamp et al., 2013), mostly as late onset deficits (deGrauw et al., 2002; Hahn et al., 2002; Kleefstra et al., 2005), we found that reduced muscle levels of $\mathrm{Cr}$ measured in mutant animals were accompanied by alterations of motor behavior. $\mathrm{CrT}^{-/ y}$ mice, indeed, showed significantly decreased home-cage-locomotor activity (particularly evident during the night period) and they were slower swimmers than $\mathrm{CrT}^{+/ y}$ mice. In contrast, we found that vulnerability to stress and anxiety responses are not sensitive to CrT deletion. Future studies using conditional mouse models with a disruption of CrT allele only in the brain tissue will be useful to dissect the role of peripheral $\mathrm{Cr}$ in the development of cognitive deficits. It has been reported that a $\mathrm{CrT}$ deletion exclusively restricted to forebrain excitatory neurons during late postnatal development induces selective learning and memory deficits without affecting motor behavior (Kurosawa et al., 2012).

Because of the importance of $\mathrm{Cr}$ in normal retinal function and development (Acosta et al., 2005), it has been suggested that an alteration of visual capabilities might play a role in the cognitive deficits displayed by $\mathrm{CrT}^{-/ y}$ animals. We reported that during the ORT sample phase all experimental groups equally explored and observed the objects, with the total exploration time of mutant mice very close to that recorded for the control group, suggesting that the visual system is not impaired in $\mathrm{CrT}^{-/ y}$ animals. In addition, to avoid possible confounding effects due to reduced visual acuity, the tank used in the Morris water maze task was surrounded by a set of extra-maze cues in a visual discrimination range detectable even by partially-sighted animals.

In conclusion, this $\mathrm{CrT}^{-/ y}$ murine model will provide a new tool for improving preclinical evaluation of potential CCDS1 intervention treatments. The results confirm previous data suggesting that CCDS1 can be well modeled in mice (Kurosawa et al., 2012; Skelton et al., 2011). Null mice display an impairment of motor behavior rarely present in human patients; however, the use of conditional mice will avoid this problem. Since CCDS1 is still an untreatable pathology, there is a compelling need for developing effective therapeutic strategies. The availability of murine models that reliably reproduce the human condition will fuel and support 
the research in this field. To assess the reproducibility and the predictive validity of promising treatments for CCDS1 as well as for other disorders, the validation of findings in more than one animal model is strongly desirable prior to launching later-stage translational or clinical projects (Katz et al., 2012). Since another invalidating hallmark of CCDS1 is the frequent occurrence of seizures, additional studies in $\mathrm{CrT}^{-/ y}$ mice analyzing the behavioral response to kainic-acid injection will be required to provide useful information about seizure susceptibility in this model.

\section{Data availability}

F1000Research: Dataset 1. Data for neurochemical and behavioral assessment in a mouse model of creatine deficiency, 10.5256/ f1000research.5369.d36153 (Baroncelli et al., 2014).

\section{Author contributions}

GC, VL and TP conceived the study. TP designed the experiments. LB, MGA, JT, EP and MM carried out the research. EA and CG provided the mouse model. LB and TP wrote the manuscript. All authors were involved in the revision of the draft manuscript and have agreed to the final content.

\section{Competing interests}

No competing interests were disclosed.

\section{Grant information}

The author(s) declared that no grants were involved in supporting this work.
Acosta ML, Kalloniatis M, Christie DL: Creatine transporter localization in developing and adult retina: importance of creatine to retinal function. $A m \mathrm{~J}$ Physiol Cell Physiol. 2005; 289(4): C1015-1023.

PubMed Abstract | Publisher Full Text

Alessandri MG, Celati L, Battini R, et al.: Gas chromatography/mass spectrometry assay for arginine: glycine-amidinotransferase deficiency. Anal Biochem. 2005; 343(2): 356-358.

PubMed Abstract | Publisher Full Text

Anselm IA, Alkuraya FS, Salomons GS, et al.: X-linked creatine transporter defect: a report on two unrelated boys with a severe clinical phenotype. $J$ Inherit Metab Dis. 2006; 29(1): 214-219.

PubMed Abstract | Publisher Full Text | Free Full Text

Baroncelli L, Alessandrì MG, Tola J, et al:: Dataset 1. Data for neurochemical and behavioral assessment in a mouse model of creatine deficiency. F1000Research. 2014

Data Source

Battini R, Leuzzi V, Carducci C, et al:: Creatine depletion in a new case with AGAT deficiency: clinical and genetic study in a large pedigree. Mol Genet Metab. 2002; 77(4): 326-331.

PubMed Abstract | Publisher Full Text

Begenisic T, Baroncelli L, Sansevero G, et al.: Fluoxetine in adulthood normalizes GABA release and rescues hippocampal synaptic plasticity and spatial memory in a mouse model of Down syndrome. Neurobiol Dis. 2014; 63: 12-19. PubMed Abstract | Publisher Full Text

Carducci C, Carducci C, Santagata S, et al:: In vitro study of uptake and synthesis of creatine and its precursors by cerebellar granule cells and astrocytes suggests some hypotheses on the physiopathology of the inherited disorders of creatine metabolism. BMC Neurosci. 2012; 13: 41 PubMed Abstract | Publisher Full Text | Free Full Text

Cecil KM, Salomons GS, Ball WS Jr, et al.: Irreversible brain creatine deficiency with elevated serum and urine creatine: a creatine transporter defect? Ann Neurol. 2001; 49(3): 401-404.

PubMed Abstract | Publisher Full Text

Chilosi A, Leuzzi V, Battini R, et al:: Treatment with L-arginine improves neuropsychological disorders in a child with creatine transporter defect. Neurocase. 2008; 14(2): 151-161.

PubMed Abstract | Publisher Full Text

deGrauw TJ, Cecil KM, Byars AW, et al: The clinical syndrome of creatine transporter deficiency. Mol Cell Biochem. 2003; 244(1-2): 45-48.

PubMed Abstract | Publisher Full Text

deGrauw TJ, Salomons GS, Cecil KM, et al.: Congenital creatine transporter deficiency. Neuropediatrics. 2002; 33(5): 232-238.

PubMed Abstract | Publisher Full Text

Farley FW, Soriano P, Steffen LS, et al.: Widespread recombinase expression using FLPeR (flipper) mice. Genesis. 2000; 28(3-4): 106-110.

PubMed Abstract | Publisher Full Text

Fons C, Arias A, Sempere A, et al:: Response to creatine analogs in fibroblasts and patients with creatine transporter deficiency. Mol Genet Metab. 2010; 99(3) 296-299.

PubMed Abstract | Publisher Full Text

Hahn KA, Salomons GS, Tackels-Horne D, et al:: X-linked mental retardation with seizures and carrier manifestations is caused by a mutation in the creatinetransporter gene (SLC6A8) located in Xq28. Am J Hum Genet. 2002; 70(5): 1349-1356.

PubMed Abstract | Publisher Full Text | Free Full Text

Item CB, Stockler-Ipsiroglu S, Stromberger C, et al.: Arginine:glycine amidinotransferase deficiency: the third inborn error of creatine metabolism in humans. Am J Hum Genet. 2001; 69(5): 1127-1133.

PubMed Abstract | Publisher Full Text | Free Full Text

Katz DM, Berger-Sweeney JE, Eubanks JH, et al:: Preclinical research in Rett syndrome: setting the foundation for translational success. Dis Model Mech. 2012; 5(6): 733-745

PubMed Abstract | Publisher Full Text | Free Full Text

Kleefstra T, Rosenberg EH, Salomons GS, et al:: Progressive intestinal, neurological and psychiatric problems in two adult males with cerebral creatine deficiency caused by an SLC6A8 mutation. Clin Genet. 2005; 68(4): 379-381.

PubMed Abstract | Publisher Full Text

Kurosawa Y, Degrauw TJ, Lindquist DM, et al.: Cyclocreatine treatment improves cognition in mice with creatine transporter deficiency. J Clin Invest. 2012; 122(8): 2837-2846.

PubMed Abstract | Publisher Full Text | Free Full Text

Lonetti G, Angelucci A, Morando L, et al.: Early environmental enrichment moderates the behavioral and synaptic phenotype of MeCP2 null mice. Biol Psychiatry. 2010; 67(7): 657-665.

PubMed Abstract | Publisher Full Text

Lowe MT, Faull RL, Christie DL, et al.: Distribution of the creatine transporter throughout the human brain reveals a spectrum of creatine transporte immunoreactivity. J Comp Neurol. 2014.

PubMed Abstract | Publisher Full Text

Lowry OH, Rosebrough NJ, Farr AL, et al.: Protein measurement with the Folin phenol reagent. J Biol Chem. 1951; 193(1): 265-275.

PubMed Abstract

Mak CS, Waldvogel HJ, Dodd JR, et al: Immunohistochemical localisation of the creatine transporter in the rat brain. Neuroscience. 2009; 163(2): 571-585.

PubMed Abstract | Publisher Full Text

Nash SR, Giros B, Kingsmore SF, et al:: Cloning, pharmacological

characterization, and genomic localization of the human creatine transporter.

Receptors Channels. 1994; 2(2): 165-174.

PubMed Abstract

Russell AP, Ghobrial L, Wright CR, et al.: Creatine transporter (SLC6A8)

knockout mice display an increased capacity for in vitro creatine biosynthesis in skeletal muscle. Front Physiol $2014 ; 5: 314$

PubMed Abstract | Publisher Full Text | Free Full Text

Schmidt A, Marescau B, Boehm EA, et al:: Severely altered guanidino compound levels, disturbed body weight homeostasis and impaired fertility in a mouse model of guanidinoacetate $\mathrm{N}$-methyltransferase (GAMT) deficiency. Hum $\mathrm{Mol}$ Genet. 2004; 13(9): 905-921.

PubMed Abstract | Publisher Full Text

Schulze A, Ebinger F, Rating D, et al:: Improving treatment of guanidinoacetate methyltransferase deficiency: reduction of guanidinoacetic acid in body fluids by arginine restriction and ornithine supplementation. Mol Genet Metab. 2001; 74(4): 413-419.

PubMed Abstract | Publisher Full Text

Skelton MR, Schaefer TL, Graham DL, et al.: Creatine transporter (CrT; SIc6a8)

knockout mice as a model of human CrT deficiency. PLOS One. 2011; 6(1): e16187.

PubMed Abstract | Publisher Full Text | Free Full Text

Stockler S, Hanefeld F, Frahm J: Creatine replacement therapy in guanidinoacetate methyltransferase deficiency, a novel inborn error of metabolism. Lancet. 1996; 348(9030): 789-790.

PubMed Abstract | Publisher Full Text 
Stockler S, Holzbach U, Hanefeld F, et al.: Creatine deficiency in the brain: a new treatable inborn error of metabolism. Pediatr Res. 1994; 36(3): 409-413. PubMed Abstract | Publisher Full Text

Tachikawa M, Fukaya M, Terasaki T, et al:: Distinct cellular expressions of creatine synthetic enzyme GAMT and creatine kinases uCK-Mi and CK-B suggest a novel neuron-glial relationship for brain energy homeostasis. Eur $J$ Neurosci. 2004; 20(1): 144-160.

PubMed Abstract | Publisher Full Text

Tang SH, Silva FJ, Tsark WM, et al:: A Cre/loxP-deleter transgenic line in mouse strain 129S1/SvImJ. Genesis. 2002; 32(3): 199-202.

PubMed Abstract | Publisher Full Text

Valayannopoulos V, Boddaert N, Chabli A, et al.: Treatment by oral creatine,

L-arginine and L-glycine in six severely affected patients with creatine

transporter defect. J Inherit Metab Dis. 2012; 35(1): 151-157.

PubMed Abstract | Publisher Full Text van de Kamp JM, Mancini GM, Salomons GS: X-linked creatine transporter deficiency: clinical aspects and pathophysiology. J Inherit Metab Dis. 2014; 37(5): 715-733.

PubMed Abstract | Publisher Full Text

van de Kamp JM, Pouwels PJ, Aarsen FK, et al:: Long-term follow-up and

treatment in nine boys with X-linked creatine transporter defect. $J$ Inherit Metab Dis. 2012; 35(1): 141-149.

PubMed Abstract | Publisher Full Text | Free Full Text

van de Kamp JM, Betsalel OT, Mercimek-Mahmutoglu S, et al:: Phenotype and genotype in 101 males with X-linked creatine transporter deficiency. $J$ Med Genet. 2013; 50(7): 463-472.

PubMed Abstract | Publisher Full Text

Wyss M, Kaddurah-Daouk R: Creatine and creatinine metabolism. Physiol Rev. 2000; 80(3): 1107-1213.

PubMed Abstract 


\title{
Open Peer Review
}

\section{Current Peer Review Status: ? $\checkmark$}

\section{Version 1}

Reviewer Report 11 November 2014

https://doi.org/10.5256/f1000research.5732.r6559

(C) 2014 Schulze A. This is an open access peer review report distributed under the terms of the Creative Commons Attribution License, which permits unrestricted use, distribution, and reproduction in any medium, provided the original work is properly cited.

\begin{abstract}
Andreas Schulze
Division of Clinical and Metabolic Genetics, Department of Pediatrics, University of Toronto, Toronto, ON, Canada

The research group generated a new ubiquitous $\mathrm{CrT}$ knockout as mouse model for creatine transporter deficiency with a large 3 exon deletion in the Slc6a8 gene. Biochemical phenotyping revealed creatine deficiency in brain, muscle, heart, and kidneys and behavioral testing revealed a phenotypic similarities with CrT patients. Therefore the new mouse model appears to be a valid tool to study creatine transporter deficiency.
\end{abstract}

What needs some more elaboration is the discrepancy in findings compared to the mouse model described by Skelton et al. (2011). Considering the similarities of the knock-outs, both have a large deletion of three exons, on would expect similar findings. But in the knock-out presented here there is more cognitive impairment, i.e. novel object recognition was abnormal while it was normal in the Skelton paper, and this is despite of the fact that the brain creatine deficiency reported here appears to be less pronounced than in the mouse model of Skelton et al.

Before indexing the authors should provide information on whether the mouse chow contained creatine (some mouse chow contains fish meal and the latter contains creatine). Also it would be important to know the creatine concentration in plasma. The creatine concentration in mutants is expected to be higher than in wild types. I wonder whether blood contamination has contributed to unexpected high brain creatine concentration in mutants. Why did the group not consider whole-body perfusion prior to organ removal? Did the authors measure creatine/creatinine ratios in urine? And why not providing the information on guanidinoacetate in organs and body fluids as well?

Competing Interests: No competing interests were disclosed.

I confirm that I have read this submission and believe that I have an appropriate level of expertise to confirm that it is of an acceptable scientific standard, however I have significant reservations, as outlined above. 
Reader Comment 16 Dec 2014

\section{Skelton Lab,}

Dr. Schulze,

I would like to respectfully clarify an error in your review. Our ubiquitous CrT mice did indeed show deficits in object recognition memory, as shown in figure 6 of our PLOS One paper. In fact, the object recognition deficit was similar to the deficit presented in this paper.

Best Regards,

Matthew R. Skelton, Ph.D.

Cincinnati Children's Research Foundation

matthew.skelton@cchmc.org

Competing Interests: We developed the first CrT KO mice.

\section{Author Response 15 Jan 2015}

Laura Baroncelli, National Research Council (CNR), Pisa, Italy

As already clarified by Dr. Skelton, our behavioral findings are not at odds with those reported in his PLOS ONE paper: indeed, their knockout mice show a deficit in object recognition memory very similar to that measured in our model. The difference in the extent of creatine deficiency is explained by the different methods employed to measure this metabolite: in our study creatine was analyzed using gas chromatography/mass spectrometry, a widely accepted specific and sensitive technique, whereas Skelton et al. (2011) used a less sensitive colorimetric method.

As regards the mouse chow, the manufacturer told us that the pellet purchased for our animal facility is not added with creatine. We made this point clearer, adding a sentence in the Materials and methods section (Animal housing subsection).

We followed your suggestion and measured creatine concentration also in body fluids, and more specifically in serum and urine. We observed a significant reduction of $\mathrm{Cr}$ in the serum of $\mathrm{CrT}^{-/}$y mice with respect to wild-type (WT) littermates (Two Way ANOVA on rank transformed data, post hoc Holm-Sidak method, $\mathrm{p}<0.001$ ). In contrast, an increase of $\mathrm{Cr}$ levels (Two Way ANOVA on rank transformed data, post hoc Holm-Sidak method, $p<0.05$ ) and creatine/ creatinine ratio was present in the urine of mutant with respect to WT animals ( $t$ test, $p<0.001$ ). We added these data in the Result section and in Table 1. We also modified the discussion adding the following sentences: "In contrast to the preservation of Cr levels in skeletal muscle of CCDS1 patients (deGrauw et al., 2003), we observed that mutant mice exhibit $\mathrm{Cr}$ reductions in muscle and other peripheral tissues and body fluids. This observation, which is in agreement with data from a different CrT knockout mouse ( Russell et al., 2014; Skelton et al., 2011), further confirmed that the recombination resulted in a ubiquitous disruption of the CrT gene. In particular, the reduction of serum $\mathrm{Cr}$ level may be explained by defective gut absorption from the diet (Garcia-Miranda et al., 2009; Skelton et al., 2011). The only body fluid in which $\mathrm{Cr}$ levels resulted to be increased is urine; it is likely that the lack of a functional transporter impairs the creatine salvage normally operated by 
the kidney (van de Kamp et al., 2014). Consistently, we found an elevated creatine/creatinine $(\mathrm{Cr} / \mathrm{Crn})$ ratio in the urine of mutant mice, probably due to a combination of reduced renal reabsorption of creatine and decreased creatinine excretion." Since we found a strong reduction of creatine concentration, we don't think that blood contamination could be responsible for higher brain $\mathrm{Cr}$ levels in these mice. Finally, we provided the information on GAA content in organs and body fluids, adding a Table 2 to the manuscript.

Competing Interests: No competing interests were disclosed.

Reviewer Report 05 November 2014

https://doi.org/10.5256/f1000research.5732.r6560

(C) 2014 Valor L. This is an open access peer review report distributed under the terms of the Creative Commons Attribution License, which permits unrestricted use, distribution, and reproduction in any medium, provided the original work is properly cited.

\section{Luis M. Valor}

Instituto de Neurociencias de Alicante (Universidad Miguel Hernández - Consejo Superior de Investigaciones Científicas), Alicante, Spain

In "A novel mouse of creatine transporter deficiency" the authors describe the phenotype of a new knockout mouse for S/c6a8 gene which is associated with a depletion in the levels of creatine in diverse organs. This phenotype is reminiscent of the CCDS1 symptomatology, therefore the main output of the present report is an increase in the number of available murine models for this disorder as claimed in the article.

The paper is well written and the work is well presented, with no major concerns regarding the data as shown. Nonetheless, I miss a more complete behavioural analysis. In some cases this is not crucial because assessment of particular tasks is expected to support current findings (absence of anxiety in the open field or impaired spatial working memory in the Y-maze) although with the strength of using more dedicated paradigms (elevated plus maze or T-maze based on a rewarding system, respectively). However, it is more relevant in the case of motor and neuromuscular deficits to enhance the conclusions obtained from spontaneous activity measurements, and other approaches (accelerating rotarod, grip strength, vertical pole, etc. to put some examples) may be more informative.

Competing Interests: No competing interests were disclosed.

\section{I confirm that I have read this submission and believe that I have an appropriate level of expertise to confirm that it is of an acceptable scientific standard.}


Laura Baroncelli, National Research Council (CNR), Pisa, Italy

We agree that a more detailed behavioral analysis (in particular dedicated to the understanding of motor and neuromuscolar deficits) would be informative for the characterization of CCDS1 murine models. We plan to do this in our next paper.

Competing Interests: No competing interests were disclosed.

Reviewer Report 02 October 2014

https://doi.org/10.5256/f1000research.5732.r6247

(C) 2014 Sacchetti B. This is an open access peer review report distributed under the terms of the Creative Commons Attribution License, which permits unrestricted use, distribution, and reproduction in any medium, provided the original work is properly cited.

\section{Benedetto Sacchetti}

Department of Neuroscience, University of Turin, Turin, Italy

In the present paper the authors describe a new murine model of CCDS1 obtained by ubiquitous deletion of 5-7 exons in the S/c6a8 gene. The experiments in general are well controlled and the results could be of interest for a general audience. However, I think there are two related points that should be added or clarified before the paper can be considered for publication.

The authors reported that $\mathrm{Cr}$ depletion altered spontaneous locomotor behavior (Fig 7) and reduced muscle levels. How can this data fit with the normal behavior (namely, the motion speed and the total distance moved) displayed by mutant animals in the open field test?

On the other hands, can the authors exclude that the aforementioned reduced motor activity may have interfere with learning and memory trials? The authors should at least discuss this possibility.

Competing Interests: No competing interests were disclosed.

\section{I confirm that I have read this submission and believe that I have an appropriate level of expertise to confirm that it is of an acceptable scientific standard, however I have significant reservations, as outlined above.}

Author Response 06 Nov 2014

Laura Baroncelli, National Research Council (CNR), Pisa, Italy

We agree that the difference between the altered spontaneous locomotor behavior of mutant animals in the home cage and the normal exploratory disposition in the open field arena can be a little bit surprising. However, we feel that the lack of a 
genotype effect for the latter measure may be due to the aversive nature of the open field arena, which may affect the explorative behavior of both wild-type and mutant mice, thus masking the difference in motor activity between the two groups.

We think that our data allow to exclude the possibility that an impaired motor activity can interfere with the presented results of learning and memory test. We found that, during the ORT sample phase, the total exploration time of objects was equal for mutant and control mice (Figure 4a), and animals of both groups equally explored the $Y$ maze in terms of both the number of entries in the single arms of the maze and the total number of arm entries (Figure $5 b$ ). These results strongly suggest that animals' level of activity does not affect their cognitive performance. As for the Morris water maze during the training phase we analyzed the path length covered to locate the submerged platform just to avoid the confounding effects of the reduced swimming speed observed in mutant mice that should not affect instead the performance in the probe trial.

Competing Interests: No competing interests were disclosed.

The benefits of publishing with F1000Research:

- Your article is published within days, with no editorial bias

- You can publish traditional articles, null/negative results, case reports, data notes and more

- The peer review process is transparent and collaborative

- Your article is indexed in PubMed after passing peer review

- Dedicated customer support at every stage

For pre-submission enquiries, contact research@f1000.com 